\title{
Effect of Zinc Nano-Fertilizer on Growth and Yield of Wheat (Triticum aestivum L.) under Saline Irrigation Condition
}

\author{
Bhavik J. Prajapati*, S.B. Patel, Rajal P. Patel and V.P. Ramani \\ Department of Soil Science and Agricultural Chemistry, Anand Agricultural \\ University, Anand-388110 Gujarat, India
}

\begin{abstract}
Zinc deficiency in cereal crops can be solved by the application of $\mathrm{Zn}$ through bio fortification. Nanotechnology is one of the options to enhance the nutritional value of crops as some engineered nanoparticles (NPs) could be used as a fertilizer. Zinc can be used in the form of zinc oxide ( $\mathrm{ZnO})$ NPs. The present study used the direct precipitation method to prepare $\mathrm{ZnO}$ NPs, characterized it by using dynamic light scattering (DLS), scanning electron microscopy (SEM) and fouriertransform infrared spectroscopy (FTIR) and then evaluated the effect of Zinc nanofertilizer on growth and yield of wheat (Triticum aestivum L.). The field experiment consisted of seed treatment, foliar application and combination of seed treatment as well as foliar application of bulk Zn sources and nano Zn source. Results showed that the seed treatment of ZnO NPs @ 1000 ppm followed by three foliar sprays of ZnO NPs@1000 ppm at 21, 45 and 90 days after sowing proved to be significantly superior in enhancing the plant height, number of effective tillers per plant, spike length, test weight, grain and straw yields, grain and straw zinc content and uptake by grain and straw.
\end{abstract}

Keywords: Zinc oxide(ZnO), nanoparticles(NPs), use efficiency, nutrient uptake

\section{Introduction}

Micronutrients are essential for increasing crop production and enhancing animal and human health. About one third of agricultural soils in the world are estimated to be low in available zinc ( $\mathrm{Zn})$, resulting in poor crop yields and nutritional quality of the harvested grains (Alloway 2008; Cakmak 2008). Among the micronutrients, $\mathrm{Zn}$ deficiency is the most detrimental to crop growth and yield of all the cereal crops including wheat (Alloway 2008; Marschner 1995). The deficiency of $\mathrm{Zn}$ in Indian as well as world soils is very well documented constraint in crop production and since last couple of decades, it is considered to be the $4^{\text {th }}$ most yield limiting nutrient after $\mathrm{N}, \mathrm{P}_{2} \mathrm{O}_{5}$, and $\mathrm{K}_{2} \mathrm{O}$ in India (Katyal and Sharma 1991; Singh 2009; Shukla et al.2014).

Cereals grains such as wheat (Triticum aestivum L.) contain only small concentrations of $\mathrm{Zn}$. Wheat is the second most important crop in India after rice and contributes nearly 35 per cent to the national food basket. India will require 109 million tons of wheat to feed the population of 1.25 billion by 2020 A.D, which can be achieved by growth rate of 2.2 per cent but the current growth rate is only $1.0 \%$.

*Corresponding author: (Email: prajapathibhavik633@gmail.com) 
The viable options for ameliorating $\mathrm{Zn}$ deficiency in soils as well as to enhance $\mathrm{Zn}$ in major food crops is limited by poor fertilizer use efficiency, which must be improved. Nano-fertilizer is required in less quantity, so it reduces the cost of fertilizers and also reduces the chemical load of fertilizers in the soil. Nanofertilizer facilitates slow and steady release of nutrients, thus enhances nutrient use efficiency by reducing loss of nutrients. The application of nano-technological formulation to agricultural crop inputs is one of the proposed tools for sustainable intensifications.

Nano-particles (NPs) could also be used as a source of essential plant nutrients (Rizwan et al. 2017; Moghaddasi et al. 2017).Among NPs, zinc oxide ( $\mathrm{ZnO}$ ) NPs are the most widely used NPs and their positive effects on the ecosystem have been reported (Rizwan et al.2017).

Nano particles are expected to be the ideal candidates for use as a $\mathrm{Zn}$ fertilizer in wheat (Adhikari et al. 2015). The seed treatment of zinc nano-fertilizers, proved as growth booster in initial crop growth period, followed by foliar spray is effective in increasing growth of crops throughout their life period. Based on this background, the present experiment was carried out to evaluate the effects of seed treatment and foliar application of zinc nano-fertilizer on growth, yield, $\mathrm{Zn}$ content, uptake and zinc use efficiency by wheat.

\section{Materials and Methods}

\section{Experimental details}

The present experiment was carried out in two parts, (i) laboratory study for synthesis and characterization of zinc oxide nanoparticles and (ii) field study to evaluate the efficacy of synthesized ZnO NPs (zinc oxide nanoparticles) on growth and yield of wheat crop.

\section{Laboratory study}

The experiment was conducted in Department of Nanotechnology and Centre for Advanced Research in Plant Tissue Culture, Anand Agricultural University. ZnO NPs were prepared by adding $1 \mathrm{~N} \mathrm{NaOH}(\mathrm{pH} 10.5)$ to the $0.1 M \mathrm{ZnSO}_{4} \cdot 7 \mathrm{H}_{2} \mathrm{O}$ solution. Then, it was centrifuged at $6000 \mathrm{rpm}$ for 10 minutes. The collected pellet was washed with Milli Q DI-water and again centrifuged at $6000 \mathrm{rpm}$ for 10 minutes. Further, 1000 ppm STPP (Sodium Tri polyphosphate) was added to the pellet and then the solution was sonicated for 10 minutes. Synthesized solution was dried at $100^{\circ} \mathrm{C}$ in hot air oven till the complete removal of water and thus dried powder obtained. After the preparation of $\mathrm{ZnO}$ NPs, different characterization techniques were used to investigate their particle size (nm), polydispersive index (PDI) and count rate (Kcps), zeta potential and morphological characteristics.

\section{Field study}

The present experiment was carried out at Agronomy Farm, College of Agriculture, Anand Agricultural University, Vaso (Gujarat) during rabi season of the year 2018-19.The soil had low available nitrogen, medium available phosphorus and available potash. The $\mathrm{Zn}$ was deficient but $\mathrm{Mn}, \mathrm{Fe}$ and $\mathrm{Cu}$ were sufficient (Table 1).

Experiment consisting of ten treatments viz. $T_{1}$ [control (only NPK)]; $\mathrm{T}_{2}\left[\mathrm{~T}_{1}+\right.$ seed treatment of $\mathrm{ZnO}$ NPs suspension at $1000 \mathrm{ppm}] ; \mathrm{T}_{3}\left[\mathrm{~T}_{1}+\right.$ seed treatment of $\mathrm{ZnO}(30 \% \mathrm{Zn}) 10 \mathrm{~mL}$ per $\mathrm{kg}$ seeds]; $\mathrm{T}_{4}\left[\mathrm{~T}_{1}+\right.$ foliar spray of $\mathrm{ZnO} \mathrm{NPs}$ at $\left.1000 \mathrm{ppm}\right]$; $\mathrm{T}_{5}\left[\mathrm{~T}_{1}+\right.$ foliar spray of $\left.0.5 \% \mathrm{ZnSO}_{4}\right] ; \mathrm{T}_{6}\left[\mathrm{~T}_{2}+\right.$ foliar spray of $\mathrm{ZnO} N$ Ps at $1000 \mathrm{ppm}]$; $\mathrm{T}_{7}\left[\mathrm{~T}_{2}+\right.$ foliar spray of $0.5 \%$ $\left.\mathrm{ZnSO}_{4}\right] ; \mathrm{T}_{8}\left[\mathrm{~T}_{3}+\right.$ foliar spray of $\mathrm{ZnO}$ NPs at $\left.1000 \mathrm{ppm}\right]$; $\mathrm{T}_{9}\left[\mathrm{~T}_{3}+\right.$ foliar spray of $\left.0.5 \% \mathrm{ZnSO}_{4}\right]$ and $\mathrm{T}_{10}\left[\mathrm{~T}_{1}+\right.$ soil application of $\mathrm{ZnSO}_{4} @ 25 \mathrm{kgha}^{-1}$ (as per STV)]was conducted in Randomized Block Design (RBD). Wheat variety GW 496 was raised under recommended dose of fertilizers (120 kg N and $60 \mathrm{Kg} \mathrm{P}_{2} \mathrm{O}_{5}$ ) was applied urea and diammonium phosphate, respectively. Phosphorus $\left(60 \mathrm{~kg} \mathrm{P}_{2} \mathrm{O}_{5} \mathrm{ha}^{-1}\right)$ and 50 per cent of nitrogen was applied as basal dose. Remaining 50 per centof nitrogen was applied two split applications at 21 and 35 days after sowing. Application of $\mathrm{ZnSO}_{4}\left(25 \mathrm{kgha}^{-1}\right)$ was carried out as per soil test value at the time of sowing. The seeds were soaked in $\mathrm{ZnO}$ NPs suspension of 1000 ppm for 2 hours and then shade-dried for an hour and then stored in plastic bags for sowing. The seeds $(1 \mathrm{Kg})$ were coated 
with slurry $(10 \mathrm{ml})$ of $\mathrm{ZnO}(30 \% \mathrm{Zn})$. Three sprays of $1000 \mathrm{ppm} \mathrm{ZnO}$ NPs and $0.5 \% \mathrm{ZnSOp}_{4}$ were done at 21 , 45 and 90 DAS in respective treatments.

Table 1.Properties of the experimental soil

\begin{tabular}{ll}
\hline Parameters & Value \\
\hline Clay $(\%)$ & 10.50 \\
Silt $(\%)$ & 10.20 \\
Fine sand (\%) & 75.25 \\
Coarse sand (\%) & 4.05 \\
Texture & Sandy loam \\
pH $(1: 2.5)$ & 8.75 \\
EC $(1: 2.5)\left(\mathrm{dSm}^{-1}\right)$ & 0.76 \\
Organic carbon $(\%)$ & 0.45 \\
Available $\mathrm{N}\left(\mathrm{kgha}^{-1}\right)$ & 204 \\
Available $\mathrm{P}_{2} \mathrm{O}_{5}\left(\mathrm{kgha}^{-1}\right)$ & 32.25 \\
Available $\mathrm{K}_{2} \mathrm{O}\left(\mathrm{kgha}^{-1}\right)$ & 206 \\
Available $\mathrm{S}\left(\mathrm{mgkg}^{-1}\right)$ & 9.30 \\
DTPA-Fe $\left(\mathrm{mgkg}^{-1}\right)$ & 5.23 \\
DTPA-Mn $\left(\mathrm{mgkg}^{-1}\right)$ & 5.78 \\
DTPA-Zn(mgkg & 0.40 \\
DTPA-Cu(mgkg $)$ & 0.32 \\
\hline
\end{tabular}

Growth and yield attributes

Days to emergence was recorded between 6 to 8 DAS. The plant height was recorded at 21, 45 DAS and at harvest. At maturity, average number of effective tillers per plant, spike length was also recorded from each plot. At harvest of the crop, grain and straw yield were computed and representative, grain and straw samples were collected for analysis. The samples were dried in paper bags at $70{ }^{\circ} \mathrm{C}$ till constant weight in a hot air oven and thereafter ground in a stainless steel grinder. Harvest index was calculated as follows:

Harvest Index $(\%)=\left[\right.$ Economic yield $\left(\mathrm{kgha}^{-1}\right) /$ Total biological yield $\left.\left(\mathrm{kgha}^{-1}\right) \times 100\right]$

\section{Soil, water and plant analysis}

Soil samples were processed and analysed for $\mathrm{pH}$ and electrical conductivity (EC) (1:2.5) using glass electrode $\mathrm{pH}$ meter and EC meter, respectively. Organic carbon was estimated by Walkley and Black (1934) method, available $\mathrm{N}$ by alkaline potassium permanganate method (Subbiah and Asija 1956), available $\mathrm{P}$ by Olsen's method (Olsen et al. 1954). Available $\mathrm{K}$ by extraction with $1 \mathrm{~N}$ ammonium acetate at pH 7.0 (Hanway and Heidal 1952) and available sulphur by turbidimetric method (Chesnin and Yien 1951). For analysis of available iron $(\mathrm{Fe})$, copper $(\mathrm{Cu})$, manganese $(\mathrm{Mn})$ and $\operatorname{zinc}(\mathrm{Zn})$, soil samples were extracted by $0.005 M$ DTPA containing $0.01 M \mathrm{CaCl}_{2}$ and $0.1 M$ TEA (pH-7.3) (Lindsay and Norvell 1978) and analysed by atomic absorption spectrophotometer. Finely ground straw and grain samples were digested with di-acid mixture $\left(\mathrm{HNO}_{3}: \mathrm{HClO}_{4}: 3: 1, \mathrm{v} / \mathrm{v}\right)$ and analysed for micronutrients using atomic absorption spectrophotometer. The underground (tube well) water samples were analysed for different water quality parameters following standard procedures..

\section{Statistical analysis}

The data were statistically analysed as per the methods by Steel and Torrie (1982). The value of ' $F$ ' was worked out and compared with value of ' $F$ ' at 5 per cent level of significance. The values of standard error (mean) (S.Em. \pm ), critical difference (C. D.) and coefficient of variation (C.V. \%) were also calculated and appropriately used for interpretation of data.

\section{Results and Discussion}

Effect of zinc nano-fertilizer on growth and yield attributes of wheat

At 21 DAS, maximum plant height $(21.18 \mathrm{~cm})$ was observed under $\mathrm{T}_{6}$ (seed treatment of $\mathrm{ZnO} \mathrm{NPs}$ suspension@1000 ppm) followed by three foliar sprays of ZnO NPs@1000 ppm at 21, 45 and 90 DAS, which was statistically at par with treatments $\mathrm{T}_{2}$ and $\mathrm{T}_{4}$.

At 45 DAS maximum plant height $(63.78 \mathrm{~cm})$ 
was observed under $\mathrm{T}_{6}$ followed by three foliar sprays of ZnO NPs@1000 ppm at 21, 45 and 90 DAS which was statistically at par with treatments $\mathrm{T}_{2}$ and $\mathrm{T}_{4}$. Similarity at harvest, maximum plant height $(93.60 \mathrm{~cm})$ was observed under $\mathrm{T}_{6}$, which was at par with $\mathrm{T}_{2}$ and $\mathrm{T}_{4}$ (Table 2). This increase in height was due to extended intermodal length. Such increase could be ascribed to higher precursor activity of $\mathrm{ZnO}$ NPs in auxin production (Kobayashi and Mizutani 1970). Adhikari et al. (2015) also reported that the application of $\mathrm{ZnO}$ nano particles on maize plant enhances plant growth as compared to conventional zinc fertilizer i.e. $\mathrm{ZnSO}_{4}$.
The maximum number of tillers per plant (9.30) were recorded with $T_{6}$ followed by three foliar sprays of ZnO NPs @ 1000 ppm at 21, 45 and 90 DAS and was statistically at par with $\mathrm{T}_{2}$ and $\mathrm{T}_{4}$.

The maximum spike length $(11.82 \mathrm{~cm})$ was associated with T6 followed by three foliar sprays of ZnO NPs @1000 ppm at 21, 45 and 90 DAS) and was statistically at par with T2 and T4. The improvement in spike length under T6 was to the tune of 51.1 per cent over control (Table 2). The result is in agreement with the findings of Potarzycki and Grzebisz (2009).

Table 2. Effect of zinc nano-fertilizer application on growth attributes of wheat

\begin{tabular}{|c|c|c|c|c|c|c|c|}
\hline \multirow{2}{*}{$\begin{array}{l}\text { Tr. } \\
\text { No. }\end{array}$} & \multirow[t]{2}{*}{ Treatment details } & \multirow{2}{*}{$\begin{array}{l}\text { Days to } \\
\text { emergence }\end{array}$} & \multicolumn{3}{|c|}{ Periodical Plant Height (cm) } & \multirow{2}{*}{$\begin{array}{l}\text { No. of } \\
\text { effective } \\
\text { tillerplant }^{-1}\end{array}$} & \multirow{2}{*}{$\begin{array}{r}\text { Spike } \\
\text { length } \\
(\mathrm{cm})\end{array}$} \\
\hline & & & 21DAS & 45 DAS & $\begin{array}{c}\text { At } \\
\text { Harvest }\end{array}$ & & \\
\hline 1 & Control & 8.1 & 15.95 & 42.85 & 73.97 & 6.35 & 7.82 \\
\hline 2 & ST-ZnO NPs & 7.6 & 20.94 & 59.98 & 88.00 & 9.20 & 10.78 \\
\hline 3 & ST-ZnO & 8.0 & 17.89 & 51.10 & 74.94 & 6.90 & 8.63 \\
\hline 4 & FS-ZnO NPs & 8.0 & 20.99 & 61.85 & 90.90 & 9.25 & 10.88 \\
\hline 5 & FS- $\mathrm{ZnSO}_{4}$ & 8.0 & 17.67 & 52.65 & 75.52 & 6.95 & 8.86 \\
\hline 6 & ST-ZnO NPs+ FS-ZnO NPs & 7.8 & 21.18 & 63.78 & 93.60 & 9.30 & 11.82 \\
\hline 7 & ST-ZnO NPs+ FS- $\mathrm{ZnSO}_{4}$ & 7.9 & 18.68 & 57.35 & 79.51 & 7.10 & 8.83 \\
\hline 8 & $\mathrm{ST}-\mathrm{ZnO}+\mathrm{FS}-\mathrm{ZnO} \mathrm{NPs}$ & 8.0 & 19.23 & 55.11 & 81.83 & 7.73 & 9.95 \\
\hline 9 & $\mathrm{ST}-\mathrm{ZnO}+\mathrm{FS}-\mathrm{ZnSO}_{4}$ & 8.0 & 18.21 & 53.30 & 74.98 & 7.30 & 9.10 \\
\hline \multirow[t]{4}{*}{10} & $\mathrm{SA}-25 \mathrm{~kg} / \mathrm{ha} \mathrm{ZnSO}_{4}(\mathrm{STV})$ & 8.0 & 17.75 & 50.35 & 73.75 & 6.80 & 8.47 \\
\hline & $\mathrm{SEm} \pm$ & 2.25 & 0.74 & 2.15 & 2.89 & 0.43 & 0.38 \\
\hline & $\mathrm{CD}$ at $5 \%$ & NS & 2.15 & 6.23 & 8.38 & 1.26 & 1.09 \\
\hline & CV $(\%)$ & 2.39 & 7.85 & 7.83 & 7.16 & 11.30 & 7.92 \\
\hline
\end{tabular}

Effects of zinc nano-fertilizer on grain and straw yield of wheat

Seed treatment of ZnO NPs suspension at 1000 ppm followed by three foliar sprays of ZnO NPs at 1000 ppm at 21, 45 and 90 DAS recorded maximum test weight (49.28 g), which was at par with $T_{2}$ and $T_{4}$
(Table 3). These results are in conformity with the findings of Delfani et al. (2014), Laware and Raskar (2014) and Prasad et al. (2012).

The grain and straw yield of wheat were significantly improved due to different treatments. The 
grain yield (4984 $\mathrm{kg} \mathrm{ha}^{-1}$ ) was maximum with seed treatment of ZnO NPs suspension @ 1000 ppm followed by foliar sprays of ZnO NPs at 1000 ppm, which was at par with T2 and T4.Straw yield $\left(6465 \mathrm{kgha}^{-1}\right)$ was maximum with seed treatment of ZnO NPs suspension @ 1000 ppm followed by foliar sprays of ZnO NPs at 1000 ppm, which was at par with T2 ,T3 and T4 (Table 3). The improvement in yield of grain and straw was to the tune of 21.4 and 33.4 per cent, respectively over control. Positive effect of $\mathrm{Zn}$ on grain yield in $\mathrm{Zn}$ deficient soil is one of the most widely documented facts (Patel 2011; Behera et al. 2015).

The effect of zinc nano-fertilizer application was not significant on harvest index of wheat over other the treatments and control.

Effects of zinc nano-fertilizer on zinc content and uptake in grain and straw of wheat
Seed treatment of ZnO NPs suspension@1000 ppm followed by foliar sprays of ZnO NPs @1000 ppm had maximum zinc content ( 31.70 and $85.65 \mathrm{mgkg}^{-1}$ ) in grain and stover of wheat (Table 4), however it was at par with $\mathrm{T}_{4}$ in case of grain-Zn content and $\mathrm{T}_{2}, \mathrm{~T}_{3}, \mathrm{~T}_{4}, \mathrm{~T}_{7}, \mathrm{~T}_{8}$ and $\mathrm{T}_{9}$ in case of straw- $\mathrm{Zn}$ content.

The application of zinc nano-fertilizer significantly increased the wheat grain and straw zinc uptake. Seed treatment of ZnO NPs suspension @1000 ppm followed by foliar sprays of ZnO NPs @1000 ppm recorded maximum zinc uptake (157.93 and 553.81 gha $^{-1}$, respectively) in wheat grain and straw, however it was at par with $\mathrm{T}_{4}$ in case of grain zinc uptake and $\mathrm{T}_{2}$ and $\mathrm{T}_{4}$ in case of straw zinc uptake.

The results are in corroboration with the findings of Prasad et al. (2012), Subbaiah et al. (2016)and Adhikari et al. (2016).

Table 3. Effect of zinc nano-fertilizer on yield attributes and yield of wheat

\begin{tabular}{|c|c|c|c|c|c|}
\hline $\begin{array}{l}\text { Tr. } \\
\text { No. }\end{array}$ & Treatment details & $\begin{array}{c}\text { Test weight } \\
\text { (g) }\end{array}$ & $\begin{array}{c}\text { Grain yield } \\
\left(\mathrm{kgha}^{-1}\right)\end{array}$ & $\begin{array}{c}\text { Stover } \\
\text { yield } \\
\left(\mathrm{kgha}^{-1}\right)\end{array}$ & $\begin{array}{c}\text { Harvest } \\
\text { Index (\%) }\end{array}$ \\
\hline 1 & Control & 42.48 & 4106 & 4847 & 46 \\
\hline 2 & ST-ZnO NPs & 48.17 & 4783 & 6217 & 43 \\
\hline 3 & $\mathrm{ST}-\mathrm{ZnO}$ & 44.63 & 4340 & 5652 & 43 \\
\hline 4 & FS-ZnO NPs & 48.20 & 4831 & 6334 & 43 \\
\hline 5 & FS- $\mathrm{ZnSO}_{4}$ & 45.13 & 4444 & 5499 & 45 \\
\hline 6 & ST-ZnO NPs+ FS -ZnO NPs & 49.28 & 4984 & 6465 & 44 \\
\hline 7 & $\mathrm{ST}-\mathrm{ZnO} \mathrm{NPs}+\mathrm{FS}-\mathrm{ZnSO}_{4}$ & 45.18 & 4469 & 5443 & 45 \\
\hline 8 & $\mathrm{ST}-\mathrm{ZnO}+\mathrm{FS}-\mathrm{ZnO} \mathrm{NPs}$ & 46.54 & 4501 & 5580 & 45 \\
\hline 9 & $\mathrm{ST}-\mathrm{ZnO}+\mathrm{FS}-\mathrm{ZnSO} 4$ & 45.48 & 4485 & 5427 & 45 \\
\hline \multirow[t]{4}{*}{10} & $\mathrm{SA}-25 \mathrm{~kg} / \mathrm{ha} \mathrm{ZnSO} 4$ (STV) & 43.68 & 4436 & 5395 & 45 \\
\hline & $\mathrm{SEm} \pm$ & 0.46 & 161.8 & 300.5 & 1.4 \\
\hline & $\mathrm{CD}$ at $5 \%$ & 1.34 & 469 & 872 & NS \\
\hline & $\mathrm{CV}(\%)$ & 2.01 & 7.13 & 10.57 & 6.45 \\
\hline
\end{tabular}


Table 4. Effect of zinc nano-fertilizer on zinc content and uptake by wheat

\begin{tabular}{|c|c|c|c|c|c|}
\hline \multirow[t]{2}{*}{$\begin{array}{l}\text { Tr. } \\
\text { No. }\end{array}$} & \multirow[t]{2}{*}{ Treatment details } & \multicolumn{2}{|c|}{ Zn content (mgkg $\left.{ }^{-1}\right)$} & \multicolumn{2}{|c|}{$\begin{array}{c}\text { Zn uptake } \\
\left(\mathrm{gha}^{-1}\right)\end{array}$} \\
\hline & & Grain & Stover & Grain & Stover \\
\hline 1 & Control & 19.84 & 50.56 & 81.91 & 245.36 \\
\hline 2 & ST-ZnO NPs & 24.03 & 79.85 & 114.81 & 496.75 \\
\hline 3 & $\mathrm{ST}-\mathrm{ZnO}$ & 21.00 & 75.15 & 91.31 & 424.46 \\
\hline 4 & FS-ZnO NPs & 29.50 & 84.75 & 142.79 & 526.85 \\
\hline 5 & FS- $\mathrm{ZnSO}_{4}$ & 25.98 & 64.55 & 115.40 & 356.50 \\
\hline 6 & ST-ZnO NPs+ FS-ZnO NPs & 31.70 & 85.65 & 157.93 & 553.81 \\
\hline 7 & $\mathrm{ST}-\mathrm{ZnO} \mathrm{NPs}+\mathrm{FS}-\mathrm{ZnSO}_{4}$ & 28.20 & 74.05 & 126.05 & 402.04 \\
\hline 8 & $\mathrm{ST}-\mathrm{ZnO}+\mathrm{FS}-\mathrm{ZnO} \mathrm{NPs}$ & 28.60 & 77.20 & 128.35 & 431.24 \\
\hline 9 & $\mathrm{ST}-\mathrm{ZnO}+\mathrm{FS}-\mathrm{ZnSO}_{4}$ & 27.30 & 75.70 & 122.14 & 411.03 \\
\hline \multirow[t]{4}{*}{10} & $\mathrm{SA}-25 \mathrm{~kg} / \mathrm{ha} \mathrm{ZnSO}_{4}(\mathrm{STV})$ & 21.15 & 52.45 & 93.95 & 279.80 \\
\hline & $\mathrm{SEm} \pm$ & 0.92 & 4.13 & 5.66 & 25.00 \\
\hline & $\mathrm{CD}$ at $5 \%$ & 2.66 & 11.99 & 16.42 & 72.55 \\
\hline & CV $(\%)$ & 7.13 & 11.48 & 9.63 & 12.11 \\
\hline
\end{tabular}

\section{Conclusion}

The findings of the present study suggested that the wheat yield, zinc content in grain and straw could be increased with the soakingof seed with $\mathrm{ZnO}$ NPs suspension at 1000 ppm for 2 hours followed by three foliar sprays of ZnO NPs@1000 ppm at 21, 45 and 90 days after sowing.

\section{References}

Adhikari, T., Kundu, S., Biswas, A.K., Tarafdar, J.C., and Subba, Rao A. (2015). Characterization of zinc oxide nano particles and their effect on growth of maize (Zea mays L.) plant. Journal of Plant Nutrition 38, 1505-1515.

Adhikari, T., Kundu, S., and Subba, Rao A. (2016). Zinc delivery to plants through seed coating with nano-zinc oxide particles. Journal of Plant Nutrition 39, 136-146.
Alloway, B.J. (2008). Zinc in Soils and Crop Nutrition. $2^{\text {nd }}$ edition, IFA, Paris.

Behera, S.K. Shukla, A.K., Singh, M.V., Wanjari, R. H., and Singh, P. (2015). Yield and zinc, copper, manganese and iron concentration in maize (Zea mays L.) grown on Vertisols as influenced by zinc application from various zinc fertilizers. Journal of Plant Nutrition 38, 1544-1557.

Cakmak, I. (2008). Enrichment of cereal grains with zinc. Agronomic or genetic biofortification. Plant and Soil 302, 1-17.

Chesnin, L., and Yien, C.H. (1951). Turbidimetric determination of available sulphur. Soil Science of Society of America Proceedings 15, 149-151.

Delfani, M., and Firozabadi, M. B. (2014). Some physiological responses of black-eyed pea to iron and magnesiumnano fertilizers. Communications in Soil Science and Plant Analysis 45, 530-540. 
Hanway, J., and Heidal, H. (1952). Soil analysis methods used in Iowa State College soil testing laboratory, Iowa State College Agricultural Bulletin 57, 1-13.

Katyal, J.C., and Sharma, B.D. (1991). DTPAextractable and total $\mathrm{Zn}, \mathrm{Cu}, \mathrm{Mn}$ and Fein Indian soils and their association with some soil properties. Geoderma 49, 165-179.

Kobayashi, Y., and Mizutani, S. (1970). Studies on the wilting treatment of corn plant: The influence of the artificial auxin control in nodes on the behaviour of rooting. Proceedings of the Crop Science Society of Japan 39, 213-220.

Laware, S.L., and Raskar, S. (2014). Influence of zinc oxide nanoparticles on growth, flowering, and seed productivity in onion. International Journal of Current Microbiology and Applied Sciences 3, 874-881.

Lindsay, W.L., and Norvell, W.A. (1978). Development of DTPA soil test for zinc, iron, manganese and copper. Soil Science Society of America Journal 42, 421-428.

Marschner, H. (1995). Mineral Nutrition of Higher Plants ( $2^{\text {nd }} E d$.) Academic Press, London, $p p$. 889.

Moghaddasi, S., Fotovat, A., Khoshgoftarmanesh, A.H., Karimzadeh, F., Khazaei, H.R., and Khorassani, R. (2017). Bioavailability of coated and uncoated $\mathrm{ZnO}$ nanoparticles to cucumber in soil with or without organic matter. Ecotoxicology and Environmental safety 144,543-551.

Olsen, S.R., Cole, C.V., Watanabe, F.S., and Dean, L.A. (1954). Estimation of available phosphorus in soils by extraction with sodium bicarbonate. USDACircular 939, Washington, DC.

Patel, K. P. (2011). Crop response to zinc-cereal crops. Indian Journal of Fertilizers 7, 84-100.

Potarzycki, J., and Grzebisz, W. (2009). Effect of zinc foliar application on grain yield of maize and it's yielding components. Plant Soil and Environment 55, 519-527.
Prasad, T.N.V.K.V., Sudhakar, P., Sreenivasulu, Y., Latha, P., Munaswamy, V., Raja, Reddy K., Sreeprasad, T.S., Sajanlal, P.R., and Pradeep, T. (2012). Effect of nanoscale zinc oxide particles on the germination, growth and yield of peanut. Journal of Plant Nutrition 35, 905-927.

Rizwan, M., Ali S., Qayyum, M.F., Ok, Y.S., Adrees, M., Ibrahim, M. and Abbas F. (2017). Effect of metal and metal oxide nanoparticles on growth and physiology of globally important food crops: a critical review. Journal of Hazardous Materials 322, 2-16.

Shukla, A.K., Tiwari, P. K., and Prakash, C. (2014). Micronutrients deficiencies vis-a-vis food and nutritional security of India. Indian Journal of Fertilisers 10, 94-112.

Singh, M.V. (2009). Micronutrient nutritional problems in soils of India and improvement for human and animal's health. Indian Journal of Fertilisers $\mathbf{5}$, 11-26.

Steel, R.G., and Torrie, J.H. (1982). Principles and procedures of statistics. McGraw Hill Book Company, New Delhi-110 001.

Subbaiah, L.V., Prasad, T.N.V. K.V., Krishna, T.G., Sudhakar P., Reddy B.R., and Pradeep, T. (2016). Novel effects of nanoparticulate delivery of zinc on growth, productivity, and zinc biofortification in maize (Zea mays L.). Journal of Agricultural and Food Chemistry 64, 3778-3788.

Subbiah, B.V., and Asija, G.L. (1956). A rapid procedure for the estimation of available nitrogen in soil. Current Science 25, 259-260.

Walkley,A., and Black, I.A. (1934). An estimation of the Digestion method of determining soil organic matter and proposed modification of the chromic acid titration method. Soil Science 37, 29-38. 